\title{
Physiological Evaluation of Wheat (Triticum aestivum L.) Genotypes at Pre-Anthesis Stage under Heat Stress Conditions
}

\author{
Munazza Nazir1, Asghari Bano ${ }^{2 *}$, Faizan Ullah ${ }^{3}$, Samiullah Khan ${ }^{4}$, Naeem Khan ${ }^{\text {* }}$ \\ ${ }^{1}$ Department of Botany, University of Azad Jammu \& Kashmir Muzaffarabad, Azad Kashmir, Pakistan \\ ${ }^{2}$ Department of Biosciences, Quaid Avenue University of Wah, Wah Cantt, Pakistan \\ ${ }^{3}$ Department of Botany, University of Science and Technology, Bannu, Pakistan \\ ${ }^{4}$ Department of Agronomy, University of Haripur, Haripur, Pakistan \\ ${ }^{5}$ Department of Agronomy, University of Florida, Gainesville, FL, USA \\ Email: ^asghari.bano@uow.edu.pk, ^naeemkhan@ufl.edu
}

How to cite this paper: Nazir, M., Bano, A., Ullah, F., Khan, S. and Khan, N. (2021) Physiological Evaluation of Wheat (Triticum aestivum L.) Genotypes at Pre-Anthesis Stage under Heat Stress Conditions. American Journal of Plant Sciences, 12, 17801790.

https://doi.org/10.4236/ajps.2021.1212124

Received: November 4, 2021

Accepted: December 10, 2021

Published: December 13, 2021

Copyright $\odot 2021$ by author(s) and Scientific Research Publishing Inc. This work is licensed under the Creative Commons Attribution International License (CC BY 4.0).

http://creativecommons.org/licenses/by/4.0/

\begin{abstract}
Experiments were conducted to analyze effects of high temperature stress on wheat at pre-anthesis growth stage. Twenty four wheat genotypes exposed to a sub optimal temperature $\left(>35^{\circ} \mathrm{C}\right)$ which showed altered physiological, biochemical and agronomic characteristics. Accumulation of proline, presence of new protein bands and higher antioxidant enzyme activity in leaves of G.7 and G.17 reflects their better adaptive response under heat stress conditions. G.17 and G.19 showed least reduction in number of spikelets per spike, biological yield and 100 grain weight. It was inferred that the genotypes G.7, G.17 and G.19 exhibited greater heat tolerance and could be recommended for cultivation under heat stress conditions.
\end{abstract}

\section{Keywords}

Heat Stress, Tolerance Mechanisms, Protein Profiling, Osmolytes

\section{Introduction}

Gaseous emissions due to human activities are substantially adding to the existing concentrations of greenhouse gases, particularly $\mathrm{CO}_{2}$, methane, chlorofluorocarbons and nitrous oxides. Different global circulation models predict that greenhouse gases will gradually increase the world's average ambient temperature. According to a report of the Intergovernmental Panel on Climatic Change (IPCC), global mean temperature will rise $0.3^{\circ} \mathrm{C}$ per decade [1] reaching ap- 
proximately $1^{\circ} \mathrm{C}$ and $3^{\circ} \mathrm{C}$ above the present value by years 2025 and 2100 , respectively, and causing global warming. This may lead to altered geographical distribution and growing season of agricultural crops [2].

Heat stress is often defined as the rise in temperature beyond a threshold level for a period of time sufficient to cause irreversible damage to plant growth and is considered a serious threat to crop production worldwide [3]. Rise in temperature results in unexpected pronounced spatial and temporal variations leading to decline in plant growth and productivity [4]. Previously, it was reported [4] that a rise in temperature of $1^{\circ} \mathrm{C}$ in the wheat growing season reduced wheat yield by $3 \%-10 \%$. The optimum temperature for wheat germination is between $20^{\circ} \mathrm{C}$ $22^{\circ} \mathrm{C}$ whereas, the base temperature is $4^{\circ} \mathrm{C}$. During the grain development, the mean maximum temperature between $25^{\circ} \mathrm{C}-32^{\circ} \mathrm{C}$ is considered moderately high and temperature between $35^{\circ} \mathrm{C}-40^{\circ} \mathrm{C}$ is considered as very high temperature [5]. Temperature is one of the most important climatic factors which affect the growth, development and yield of the wheat. In wheat, the rate of grain filling can be decreased by high temperature $\left(>31^{\circ} \mathrm{C}\right)$ after anthesis [6]. High temperature episodes occurring near to anthesis can reduce the number of grains per ear and subsequently the rate of harvesting index resulting in smaller grain yields [7]. During recent years, wheat production faces very harsh environmental conditions, especially heat stress at pre-anthesis to physiological maturity. So, it is not sufficient to fulfill the needs of an ever increasing population.

The key adaptive mechanism to heat stress involves accumulation of a variety of osmolytes such as proline [8] [9] and antioxidant enzymes [10]. Under high temperature, free proline is involved in osmotic adjustment, protecting pollen and several plant enzymes from heat injury and serving as a source of nitrogen and other metabolites [11] [12]. Accumulation of proline under heat stress occurs in Arabidopsis [13], canola [14], cotton [15] and wheat [16]. Therefore, the current study was conducted to: 1) find out the physiological and biochemical basis of heat stress tolerance in wheat for breeding programs and 2) to analyze the impacts of high temperature stress on wheat genotypes at pre-anthesis stage.

\section{Material and Methods}

Twenty four wheat genotypes (Table 1) obtained from Wheat Wide Crosses Lab National Agriculture Research Centre Islamabad Pakistan were used in the study. Experiments were conducted both in vitro and in vivo during 2009-2010 to analyze the effect of high temperature stress imposed during pre-anthesis growth stages.

The seeds were grown in pots $(30 \times 40 \mathrm{~cm}$ size $)$ containing $10 \mathrm{~kg}$ sandy loam soil in a glass house with average day/night temperature $30^{\circ} \mathrm{C} \pm\left(8^{\circ} \mathrm{C}\right)$ and $13^{\circ} \mathrm{C}$ $\pm\left(5^{\circ} \mathrm{C}\right)$ during the regular wheat crop season at National Agricultural Research Centre, Islamabad (latitude $33.38 \mathrm{~N}$, longitude $73.00 \mathrm{E}$ ) from November to May respectively.

Plants were subjected to heat shocks at pre-anthesis (80 DAS) stage when the first anther extrusion occurred. The pots of four replications for each treatment, 
Table 1. Different genotypes used in the experiment.

1) Itapua 40-Obligado,

2) Skauz $2 /$ FCT,

3) Kauz/weaver,

4) CMH84.3379/CMH78.578//MILAN,

5) CROC_1/AE.Squarrosa (205)//Kauz/3/Attila

6) Weaver/4/NAC/TH.AC//3*PVN/3/MIROL/BUC

7) SITE/MO/4/NAC/TH.AC//3*PVN/3/MIRLO/BUC

8) CHEN/AEGILOPS Saquarrosa (TAUS)//BCN/3/VEE37/

9) MUNIA/CHTO/3/PFAU/BOW//VEE\#9/4/CHEN/.....

10) $\mathrm{CAL} / \mathrm{NH} / / \mathrm{H} 567.71 / 3 / \mathrm{SERI} / 4 / \mathrm{CAL} / \mathrm{NH} / / \mathrm{H} 567.71 / 5 /$

11) CHEN/AEGILOPS SQUARROSA (TAUS)//BCN/3/

12) TAM $200 / \mathrm{TUI}$
13) HD2329/SABUF

14) $\mathrm{HD} 2136 / \mathrm{SKA} / 5 / \mathrm{TOB} / \mathrm{CNO} 67 / / \mathrm{BB} / 4 / \mathrm{NAI} 60 \star 2 / / \mathrm{TT} / \ldots$..

15) TIA.4/WL6572//RL6043/3*GEN/3/LUAN

16) BCN//CETA/AE.SQUARROSA

17) ALTAR 84/AE.SQUARROSA (219)//OPATA

18) SABUF/7/ALTAR84/AE.SQUARROSA

(224)//YACO/6/CROC_1/AE.SQUARROSA (205)/5/BR12*3/4/...

19) $\mathrm{BCN} / 4 / 68.111 / \mathrm{RGB}-\mathrm{U} / / \mathrm{WARD} / 3 / \mathrm{AE} . S Q U A R R O S A(325)$

20) $\mathrm{SABUF/7/ALTAR84/AE/SQUARROSA}$

(224)//YACO/6/CROC_1/AE.SQUARROSA (205)/5/BR12*3/4/

21) ABUF/7/ALTAR84/AE/SQUARROSA

(224)//YACO/6/CROC_1/AE.SQUARROSA (205)/5/BR12*3/4/...

22) ALTAR84/AE.SQUARROSA

(191)//OPATA/3/ALTAR84/AE.SQUARROSA (224)//YACO

23) GAN/AE.SQUARROSA (236)//CETA/AE.SQUARROSA

(895)/3/MAIZ

24) DOY/AE.SQUARROSA (447)//CETA/AE/SQUARROSA

(895)/3/MAIZ.

each containing 4 - 5 plants were moved to a controlled environment glasshouse for heat shocks where temperature was maintained at $40^{\circ} \mathrm{C}-45^{\circ} \mathrm{C}$ and $50 \% / 70 \%$ relative humidity and illumination of $335 \mu \mathrm{mol} \cdot \mathrm{m}^{-2} \cdot \mathrm{s}^{-2}$. Plants were exposed to high temperature stress for $3 \mathrm{~h}$ consecutive ten days and then transferred to the greenhouse under natural daylight and $25^{\circ} \mathrm{C} / 20^{\circ} \mathrm{C}$ day night temperature. Control and heat stressed plants were irrigated regularly as and when required.

Just after heat shock treatments, leaf sampling were done of the top fully emerged young leaves from control and stressed plants for analyses of proline, soluble protein, protein profiling, superoxide dismutase (SOD) and peroxidase (POD) activities.

For proline extraction [17], fresh plant tissue was extracted with $3 \%$ aqueous 5 -sulfosalicylic acid and the filtrate was reacted with ninhydrin solution at $100^{\circ} \mathrm{C}$ for $1 \mathrm{~h}$. The reaction mixture was extracted with toluene and the absorbance of the chromophore containing toluene was read at $520 \mathrm{~nm}$.

The POD activity was measured [18] following the assay mixture containing $0.1 \mathrm{ml}$ enzyme extract, $1.35 \mathrm{ml}$ of $100 \mathrm{mM}$ MES (Methyl ethane sulphate) buffer ( $\mathrm{pH} 5.5$ ), $0.05 \% \mathrm{H}_{2} \mathrm{O}_{2}$ and $0.1 \%$ phenylene diamine. Change in absorbance was recorded at $485 \mathrm{~nm}$ for $3 \mathrm{~min}$ with a spectrophotometer. The activity of POD was presented as OD $485 \mathrm{~nm} / \mathrm{min} \mathrm{mg}$ protein.

SOD activity was determined by measuring inhibition of photochemical reduction of nitro blue tetrazolium (NBT) using method of Beauchamp and Fridovich [19]. The reaction mixture $(3 \mathrm{ml})$ was composed of $13 \mathrm{mM}$ methionine, $0.075 \mathrm{mM}$ NBT, $0.1 \mathrm{mM}$ EDTA, $0.002 \mathrm{mM}$ riboflavin and $0.1 \mathrm{ml}$ of enzyme extract in $50 \mathrm{mM}$ phosphate buffer ( $\mathrm{pH} \mathrm{7.8).} \mathrm{The} \mathrm{mixture} \mathrm{in} \mathrm{tube} \mathrm{was} \mathrm{placed} \mathrm{below}$ light chamber for $15 \mathrm{~min}$. The absorbance was read at $560 \mathrm{~nm}$ with a spectrophotometer. One unit of enzyme activity was taken as that quantity of enzyme, 
which reduces the absorbance reading to $50 \%$ in comparison with tube lacking enzyme.

For extraction of protein 5 to $7 \mathrm{~cm}$ long fresh leaves of wheat were grounded to fine powder using liquid Nitrogen. Four hundred micro-liter protein extraction buffer containing ( $0.6057 \mathrm{~g}$ Tris, $0.2 \mathrm{~g}$ SDS, $30 \mathrm{~g}$ urea, $70 \mathrm{ml}$ distilled water + conc. $\mathrm{HCl}, 1 \mathrm{ml} \mathrm{B}$-meracapto ethanol was added to $0.01 \mathrm{~g}$ of leaf powder and vortexed. The homogenized samples were centrifuged at 13,000 rpm for $10 \mathrm{~min}$, at $4^{\circ} \mathrm{C}$ in a refrigerated centrifuge. The extracted crud proteins were recovered as supernatant, transferred into a new $1.5 \mathrm{ml}$ eppendorf tube and stored at $2^{\circ} \mathrm{C}$ until they were run on polyacrylamide gel [20].

The electrophoresis procedure was carried out using SDS-PAGE (Bio-RAD, Model 600 , UK) with $15 \%$ polyacrylamide gel. The molecular weight of the dissolved proteins was estimated by using molecular weight standard protein marker, (FERMENTAS Germany), molecular weight range \# SM 0671, having 10 - 170 $\mathrm{kDa}$.

At physiological maturity, 100 grain weight, no of spikelet per spike, no of floret per plant and plant biomass of both the stressed and control plants were recorded.

\section{Statistical analysis}

The analysis of variance of data for each attribute was carried using Minitab version 13.1. Data were analyzed using a completely randomized design three factor factorial arrangement where factor $\mathrm{A}=$ varieties, factor $\mathrm{B}=$ treatments $\mathrm{C}$ = replicates. The treatment means were compared by Duncan's multiple Range Test (DMRT) and Least Significant Difference (LSD) test of probability levels of 0.05 (Steel and Torrie 1984).

\section{Result and Discussion}

Heat stress is responsible for changes in physiological processes of plants. In this study heat stress significantly increased proline accumulation in leaves of all the wheat genotypes. The highest proline content was observed in genotype G.7 (90\%) whereas; genotype G.16 has least proline content as compared to control (Table 1). Plants accumulate osmolytes like proline in response to abiotic stresses to protect the biomolecules of the cell [21]. Over accumulation of osmolytes such as proline may help plants to tolerate stress by improving their ability to maintain osmotic balance within the cell [22]. According to Wahid and Close [23], proline accumulation may buffer cellular redox potential under heat and other environmental stresses.

Heat stress significantly increased protein content in different wheat genotypes. However, highest protein content was observed in genotype G.7 (73\%) whereas, least protein content was observed in G.10, as compared to control. The protein content in genotype G.14 was approximate to G.7. However, the extent of increase in protein content was relatively higher in G.7 then G.14 (Table 2). 
Table 2. Proline, protein, SOD, POD, 100 grain weight, Spikelets per spike, florets per spike, biomass/plant of wheat genotypes under control and pre-anthesis stage heat stress conditions.

\begin{tabular}{|c|c|c|c|c|c|c|c|c|c|c|c|c|c|c|c|c|}
\hline \multirow[t]{2}{*}{ varieties } & \multicolumn{2}{|c|}{$\begin{array}{l}\text { Proline contents } \\
\quad(\mu \mathrm{g} / \mathrm{g} \text { f.w })\end{array}$} & \multicolumn{2}{|c|}{$\begin{array}{c}\text { Protein contents } \\
\qquad(\mu \mathrm{g} / \mathrm{g})\end{array}$} & \multicolumn{2}{|c|}{$\begin{array}{l}\text { SOD activity } \\
\text { (units/g f.w) }\end{array}$} & \multicolumn{2}{|c|}{$\begin{array}{l}\text { POD activity } \\
\text { (units/g f.w) }\end{array}$} & \multicolumn{2}{|c|}{$\begin{array}{l}100 \text { Grain } \\
\text { weight }\end{array}$} & \multicolumn{2}{|c|}{$\begin{array}{l}\text { No. of Spike } \\
\text { lets per spike }\end{array}$} & \multicolumn{2}{|c|}{$\begin{array}{l}\text { No of florets } \\
\text { per plants }\end{array}$} & \multicolumn{2}{|c|}{ Biomass plant } \\
\hline & Control & Stress & Control & Stress & Control & 1 Stress & Control & Stress & Control & Stress & Control & Stress & Control & Stress & Control & Stress \\
\hline \multirow{2}{*}{1} & 785.73 & 2114.73 & 1367.83 & 351.10 & 12.33 & 25.16 & 1.21 & 0.57 & 3.693 & 2.432 & 22.3 & 21.6 & 67.0 & 65.0 & 4.4 & 4.0 \\
\hline & $\mathrm{H}-\mathrm{L}$ & E - I & A & $\mathrm{AB}$ & $\mathrm{C}-\mathrm{H}$ & $\mathrm{A}-\mathrm{H}$ & A & $\mathrm{DEF}$ & $A-D$ & JKL & A & $\mathrm{AB}$ & A & $\mathrm{AB}$ & B - G & D - I \\
\hline \multirow{2}{*}{2} & 767.80 & 1793.40 & 1169.93 & 1253.60 & 10.80 & 26.28 & 0.76 & 0.86 & 3.913 & 2.643 & 21.6 & 20.3 & 65.0 & 61.0 & 4.3 & 3.2 \\
\hline & $\mathrm{H}-\mathrm{L}$ & E - J & $\mathrm{F}-\mathrm{N}$ & A - J & $\mathrm{C}-\mathrm{H}$ & A - H & B - F & B - E & A & $\mathrm{H}-\mathrm{L}$ & $\mathrm{AB}$ & $\mathrm{AB}$ & $\mathrm{AB}$ & $\mathrm{AB}$ & $\mathrm{C}-\mathrm{H}$ & $\mathrm{I}-\mathrm{M}$ \\
\hline \multirow{2}{*}{3} & 416.10 & 255.90 & 1320.27 & 1301.77 & 10.67 & 24.44 & 0.77 & 0.84 & 3.640 & 2.467 & 22.3 & 21.0 & 67.0 & 63.0 & 3.2 & 2.5 \\
\hline & JKL & $\mathrm{KL}$ & A - E & A - F & $\mathrm{C}-\mathrm{H}$ & A - H & B - F & $B-F$ & A - D & JKL & A & $\mathrm{AB}$ & A & $\mathrm{AB}$ & $\mathrm{I}-\mathrm{M}$ & MN \\
\hline \multirow{2}{*}{4} & 677.07 & 5164.90 & 1356.67 & 1278.57 & 11.27 & 23.36 & 0.84 & 0.76 & 3.850 & 2.650 & 21.3 & 20.3 & 63.0 & 61.0 & 3.9 & 3.5 \\
\hline & $\mathrm{H}-\mathrm{L}$ & $\mathrm{C}$ & A & A - I & $\mathrm{C}-\mathrm{H}$ & $\mathrm{A}-\mathrm{H}$ & B - F & $\mathrm{B}-\mathrm{F}$ & $\mathrm{AB}$ & $\mathrm{H}-\mathrm{L}$ & $\mathrm{AB}$ & $\mathrm{AB}$ & $\mathrm{AB}$ & $\mathrm{AB}$ & E - J & $\mathrm{H}-\mathrm{L}$ \\
\hline \multirow{2}{*}{5} & 1171.50 & 2132.20 & 1342.93 & 1290.00 & 16.60 & 21.07 & 0.71 & 0.70 & 3.140 & 2.667 & 21.0 & 20.3 & 63.0 & 61.0 & 3.8 & 3.6 \\
\hline & $F-L$ & E - I & $\mathrm{ABC}$ & $A-H$ & $\mathrm{~A}-\mathrm{H}$ & A - H & B - F & B - F & $\mathrm{D}-\mathrm{H}$ & $\mathrm{H}-\mathrm{L}$ & $\mathrm{AB}$ & $\mathrm{AB}$ & $\mathrm{AB}$ & $\mathrm{AB}$ & $E-K$ & $\mathrm{H}-\mathrm{L}$ \\
\hline \multirow{2}{*}{6} & 1332.60 & 1565.07 & 1250.93 & 1288.57 & 14.87 & 26.74 & 0.66 & 0.79 & 3.293 & 2.183 & 21.6 & 21.0 & 65.0 & 63.0 & 5.2 & 4.4 \\
\hline & $F-L$ & $E-L$ & A - K & $\mathrm{A}-\mathrm{H}$ & $\mathrm{A}-\mathrm{H}$ & $\mathrm{A}-\mathrm{H}$ & B - F & B - F & $C-G$ & $\mathrm{~L}$ & $\mathrm{AB}$ & $\mathrm{AB}$ & $\mathrm{AB}$ & $\mathrm{AB}$ & $\mathrm{AB}$ & B - G \\
\hline \multirow{2}{*}{7} & 444.28 & 4290.37 & 1059.87 & 1403.07 & 12.63 & 35.33 & 0.72 & 0.85 & 3.497 & 3.383 & 20.3 & 20.3 & 61.0 & 61.0 & 3.8 & 3.6 \\
\hline & JKL & $\mathrm{C}$ & MNO & IJKL & $\mathrm{B}-\mathrm{H}$ & A & B - F & B - F & $A-E$ & A - E & $\mathrm{AB}$ & $\mathrm{AB}$ & $\mathrm{AB}$ & $\mathrm{AB}$ & E - I & $\mathrm{H}-\mathrm{L}$ \\
\hline \multirow{2}{*}{8} & 2554.33 & 4595.90 & 1167.57 & 1369.00 & 13.93 & 34.79 & 0.69 & 0.55 & 3.413 & 3.070 & 19.6 & 17.6 & 59.0 & 53.0 & 5.4 & 4.6 \\
\hline & $\mathrm{EF}$ & $\mathrm{C}$ & F - N & A & $\mathrm{A}-\mathrm{H}$ & $\mathrm{AB}$ & B - F & $\mathrm{EF}$ & $\mathrm{A}-\mathrm{E}$ & $\mathrm{E}-\mathrm{H}$ & $\mathrm{ABC}$ & $\mathrm{BCDE}$ & $\mathrm{ABC}$ & $\mathrm{BCDE}$ & A & A - F \\
\hline \multirow{2}{*}{9} & 888.87 & 8877.00 & 1191.67 & 1296.77 & 20.33 & 23.93 & 0.52 & 0.64 & 3.150 & 2.463 & 19.6 & 17.6 & 59.0 & 53.0 & 4.6 & 4.3 \\
\hline & G - L & A & $\mathrm{D}-\mathrm{M}$ & A - F & $\mathrm{A}-\mathrm{H}$ & $\mathrm{A}-\mathrm{H}$ & $\mathrm{F}$ & B - F & $\mathrm{D}-\mathrm{H}$ & JKL & $\mathrm{ABC}$ & BCDE & $\mathrm{ABC}$ & $\mathrm{BCDE}$ & A - F & $\mathrm{C}-\mathrm{H}$ \\
\hline \multirow{2}{*}{10} & 2345.80 & 1740.00 & 1149.97 & 1290.63 & 7.77 & 23.54 & 0.55 & 0.80 & 3.317 & 2.413 & 21.0 & 19.0 & 63.0 & 57.0 & 3.6 & 3.2 \\
\hline & EFG & $E-K$ & $\mathrm{H}-\mathrm{O}$ & $A-G$ & FGH & FGH & $\mathrm{EF}$ & $\mathrm{B}-\mathrm{F}$ & B - F & JKL & $\mathrm{AB}$ & A - D & $\mathrm{AB}$ & $\mathrm{ABCD}$ & G - L & I - M \\
\hline \multirow{2}{*}{11} & 1994.10 & 4072.03 & 1203.70 & 1327.30 & 6.40 & 26.67 & 0.58 & 0.91 & 3.777 & 2.543 & 20.3 & 14.3 & 61.0 & 43.0 & 4.7 & 3.4 \\
\hline & E - I & $\mathrm{CD}$ & $C-L$ & $A-D$ & GH & A - H & $C-F$ & $\mathrm{BC}$ & $\mathrm{ABC}$ & IJKL & $\mathrm{AB}$ & $\mathrm{EF}$ & $\mathrm{AB}$ & $\mathrm{EF}$ & $A-E$ & $\mathrm{I}-\mathrm{L}$ \\
\hline 12 & 1637.37 & 6921.50 & 1197.23 & 1311.17 & 8.20 & 25.07 & 0.70 & 0.60 & 3.227 & 3.100 & 19.6 & 19.0 & 59.0 & 57.0 & 4.6 & 4.4 \\
\hline 12 & $E-L$ & B & $D-L$ & A - E & $\mathrm{E}-\mathrm{H}$ & $\mathrm{A}-\mathrm{H}$ & B - F & $C-F$ & $\mathrm{D}-\mathrm{G}$ & $\mathrm{D}-\mathrm{H}$ & $\mathrm{ABC}$ & A - D & $\mathrm{ABC}$ & $\mathrm{ABCD}$ & A - F & B - G \\
\hline 13 & 1708.73 & 2139.60 & 1203.40 & 1305.00 & 11.17 & 27.36 & 0.57 & 0.72 & 3.307 & 3.140 & 19.6 & 18.3 & 59.0 & 55.0 & 4.9 & 3.5 \\
\hline 13 & $E-L$ & E - H & $C-L$ & A - F & $\mathrm{C}-\mathrm{H}$ & $\mathrm{A}-\mathrm{H}$ & DEF & B - F & B - F & $\mathrm{D}-\mathrm{H}$ & $\mathrm{ABC}$ & $A-E$ & $\mathrm{ABC}$ & $\mathrm{ABCDE}$ & $A-C$ & $\mathrm{H}-\mathrm{L}$ \\
\hline 14 & 1761.63 & 1329.40 & 1151.13 & 1338.47 & 8.50 & 30.03 & 0.68 & 0.83 & 3.680 & 2.757 & 19.6 & 17.6 & 59.0 & 53.0 & 4.8 & 3.6 \\
\hline 14 & $E-K$ & $F-L$ & $\mathrm{G}-\mathrm{O}$ & $\mathrm{ABC}$ & $\mathrm{D}-\mathrm{H}$ & A - E & B - F & B - F & $A-D$ & $G-L$ & $\mathrm{ABC}$ & $B-E$ & $\mathrm{ABC}$ & $\mathrm{BCDE}$ & $A-D$ & $G-L$ \\
\hline 15 & 1752.90 & 1040.27 & 1140.00 & 1355.23 & 9.73 & 29.45 & 0.55 & 0.84 & 3.427 & 2.121 & 20.3 & 19.6 & 61.0 & 59.0 & 4.3 & 3.6 \\
\hline $1 J$ & $E-K$ & $F-L$ & $\mathrm{I}-\mathrm{O}$ & A & $\mathrm{C}-\mathrm{H}$ & A - F & $\mathrm{EF}$ & B - F & $A-E$ & $\mathrm{~L}$ & $\mathrm{AB}$ & $\mathrm{ABC}$ & $\mathrm{AB}$ & $\mathrm{ABC}$ & $\mathrm{C}-\mathrm{H}$ & $G-L$ \\
\hline 16 & 1604.23 & 189.60 & 1079.73 & 1180.80 & 6.03 & 21.93 & 0.87 & 0.61 & 3.127 & 2.870 & 17.6 & 15.6 & 53.0 & 47.0 & 3.9 & 3.0 \\
\hline & $E-L$ & $\mathrm{~L}$ & $\mathrm{~L}-\mathrm{O}$ & $E-M$ & $\mathrm{H}$ & A - H & $B-E$ & B - F & $\mathrm{D}-\mathrm{H}$ & F - K & B - E & $C-F$ & BCDE & CDEF & $E-J$ & KLM \\
\hline 17 & 492.37 & 350.73 & 1053.06 & 1168.74 & 5.23 & 25.08 & 0.89 & 0.83 & 3.6 & 3.5 & 18.3 & 18.3 & 55.0 & 55.0 & 4.7 & 4.5 \\
\hline 17 & $F-L$ & JKL & MNO & $\mathrm{F}-\mathrm{N}$ & $\mathrm{H}$ & A - H & BCD & B - F & $A-E$ & A - E & A - E & $A-E$ & $\mathrm{ABCDE}$ & $\mathrm{ABCDE}$ & $A-E$ & B - F \\
\hline 18 & 31.97 & 1658.07 & 1111.80 & 1192.27 & 12.23 & 23.73 & 0.76 & 0.85 & 3.617 & 2.947 & 18.3 & 17.6 & 55.0 & 53.0 & 4.0 & 2.1 \\
\hline 18 & $\mathrm{H}-\mathrm{L}$ & $E-L$ & $\mathrm{~K}-\mathrm{O}$ & $D-M$ & $\mathrm{C}-\mathrm{H}$ & $\mathrm{A}-\mathrm{H}$ & B - F & B - F & $A-D$ & E - J & $\mathrm{A}-\mathrm{E}$ & B - E & $\mathrm{ABCDE}$ & $\mathrm{BCDE}$ & D - I & $\mathrm{N}$ \\
\hline 10 & 349.37 & 1065.17 & 1033.06 & 1349.37 & 10.67 & 24.13 & 0.84 & 0.74 & 3.440 & 3.402 & 17.6 & 17.6 & 53.0 & 53.0 & 3.1 & 2.9 \\
\hline 19 & JKL & $F-L$ & NO & $\mathrm{AB}$ & $\mathrm{C}-\mathrm{H}$ & A - H & B - F & $B-F$ & $A-E$ & A - E & B - E & $B-E$ & BCDE & BCDE & $J-M$ & LM \\
\hline 20 & 374.20 & 194.23 & 1129.67 & 1188.16 & 8.37 & 20.47 & 0.82 & 0.65 & 3.407 & 2.780 & 21.0 & 19.0 & 63.0 & 57.0 & 4. & 3.6 \\
\hline 20 & JKL & $\mathrm{L}$ & $\mathrm{J}-\mathrm{O}$ & $D-M$ & $\mathrm{D}-\mathrm{H}$ & $\mathrm{A}-\mathrm{H}$ & B - F & B - F & $\mathrm{A}-\mathrm{E}$ & $G-K$ & $\mathrm{AB}$ & $A-D$ & $\mathrm{AB}$ & $\mathrm{ABCD}$ & $\mathrm{C}-\mathrm{H}$ & $G-L$ \\
\hline
\end{tabular}




\begin{tabular}{|c|c|c|c|c|c|c|c|c|c|c|c|c|c|c|c|c|}
\hline \multicolumn{17}{|c|}{ Continued } \\
\hline \multirow{2}{*}{21} & 933.97 & 1201.40 & 1015.46 & 1194.89 & 16.20 & 30.97 & 0.67 & 0.94 & 3.150 & 2.397 & 19.6 & 13.0 & 59.0 & 39.0 & 5.0 & 4.3 \\
\hline & $G-L$ & F - L & $\mathrm{O}$ & $\mathrm{D}-\mathrm{L}$ & $\mathrm{A}-\mathrm{H}$ & $\mathrm{ABC}$ & B - F & $\mathrm{AB}$ & $\mathrm{D}-\mathrm{H}$ & $\mathrm{KL}$ & $\mathrm{ABC}$ & $\mathrm{F}$ & $\mathrm{ABC}$ & $\mathrm{F}$ & $\mathrm{ABC}$ & $\mathrm{C}-\mathrm{H}$ \\
\hline \multirow{2}{*}{22} & 453.37 & 1876.30 & 1183.18 & 1195.17 & 14.97 & 28.37 & 0.81 & 0.89 & 3.090 & 2.377 & 19.6 & 15.0 & 59.0 & 45.0 & 3.9 & 3.4 \\
\hline & $J-L$ & $E-J$ & $\mathrm{E}-\mathrm{M}$ & D - L & $\mathrm{A}-\mathrm{H}$ & A - G & B - F & $\mathrm{BCD}$ & $\mathrm{D}-\mathrm{H}$ & $\mathrm{KL}$ & $\mathrm{ABC}$ & DEF & $\mathrm{BC}$ & DEF & E - J & I - L \\
\hline \multirow{2}{*}{23} & 1136.03 & 847.90 & 1077.12 & 1209.57 & 11.63 & 28.80 & 0.88 & 0.82 & 3.640 & 2.790 & 18.3 & 14.3 & 55.0 & 46.3 & 3.8 & 3.4 \\
\hline & $F-L$ & G - L & $\mathrm{L}-\mathrm{O}$ & $C-\mathrm{L}$ & $\mathrm{C}-\mathrm{H}$ & A - F & B - E & $\mathrm{B}-\mathrm{F}$ & $A-D$ & $\mathrm{G}-\mathrm{K}$ & $\mathrm{A}-\mathrm{E}$ & $\mathrm{EF}$ & $A-E$ & DEF & $\mathrm{F}-\mathrm{K}$ & $\mathrm{I}-\mathrm{L}$ \\
\hline \multirow{2}{*}{24} & 376.97 & 596.53 & 1133.23 & 1212.20 & 15.40 & 30.53 & 0.71 & 0.74 & 3.163 & $3.005 \mathrm{E}$ & 19.0 & 15.6 & 57.0 & 47.0 & 3.8 & 3.6 \\
\hline & JKL & I - L & $\mathrm{J}-\mathrm{O}$ & B - L & $\mathrm{A}-\mathrm{H}$ & $A-D$ & B - F & $\mathrm{B}-\mathrm{F}$ & $D-G$ & $-I$ & $A-D$ & $C-F$ & $A-D$ & $C-F$ & $F-K$ & G - L \\
\hline LSD & \multicolumn{2}{|c|}{1291} & \multicolumn{2}{|c|}{99.95} & \multicolumn{2}{|c|}{18.66} & \multicolumn{2}{|c|}{0.6349} & \multicolumn{2}{|c|}{0.4384} & \multicolumn{2}{|c|}{3.439} & \multicolumn{2}{|c|}{10.30} & \multicolumn{2}{|c|}{0.7514} \\
\hline
\end{tabular}

The effect of heat stress treatments on the change of protein patterns in 10 wheat genotypes grown under control and heat stressed conditions are presented in Figure 1(a) and Table 2. The SDS-PAGE showed the Band of $72 \mathrm{kDa}$ appears under heat stress condition in 9 genotypes but the same polypeptide band was present in G.10 both in control and heat stressed treatment. A new protein of molecular weight $35 \mathrm{kDa}$ appeared in genotype G.7 only. The protein profile of wheat genotypes G.11 - G.20 is presented in Figure 1(b); Table 2. In all the ten genotypes (G.11 - G.20) polypeptides of $26 \mathrm{kDa}, 43 \mathrm{kDa}$ and $55 \mathrm{kDa}$ appeared during both control and heat stress conditions. Only G.17 was observed with a new protein of molecular weight $20 \mathrm{kDa}$ under heat stress. Protein profiling of wheat genotypes G.21 - G.24 is presented in the Figure 1(c); Table 2. A protein band of $55 \mathrm{kDa}$ appeared during both control and heat stress in four wheat genotypes (G.21 - G.24), while a band of $72 \mathrm{kDa}$ appeared in G.21 and G.22 both under control and heat stress. A new protein band of $25 \mathrm{kDa}$ was observed in G.24 under heat stress treatment.

Accumulation of soluble proteins under heat stress is a common phenomenon in plants [24] [25] [26] [27]. Expression of stress proteins is an important adaptation to cope with environmental stresses. Most of the stress proteins are soluble in water and therefore contribute to stress tolerance presumably via hydration of cellular structures [28].

Under heat stress activities of superoxide dismutase and peroxidase were increased. However, the response of different genotypes to applied heat stress was different. The highest SOD activity was observed in genotype G.17 followed by G.11, G.16, and G.14. Least, SOD activity was observed in G.5. The genotype G.17 showed 79\% increase in SOD activity under heat stress treatment imposed at pre-anthesis growth stage as compared to control.

The highest POD activity was observed in G.23 (65\%) followed by G.1, G.22 and G.8 whereas; least POD activity was observed in G.17 as compared to control.

Genotypes having more SOD and POD activity become tolerant to heat stress. It has been reported that heat tolerance in crop plants is associated with an increase in antioxidant enzyme activity [29] [30] [31] and the same was observed during present study. Protective roles of the antioxidant enzymes in temperature stress have been reported for a number of plants [32] [33] [34] [35] [36]. 


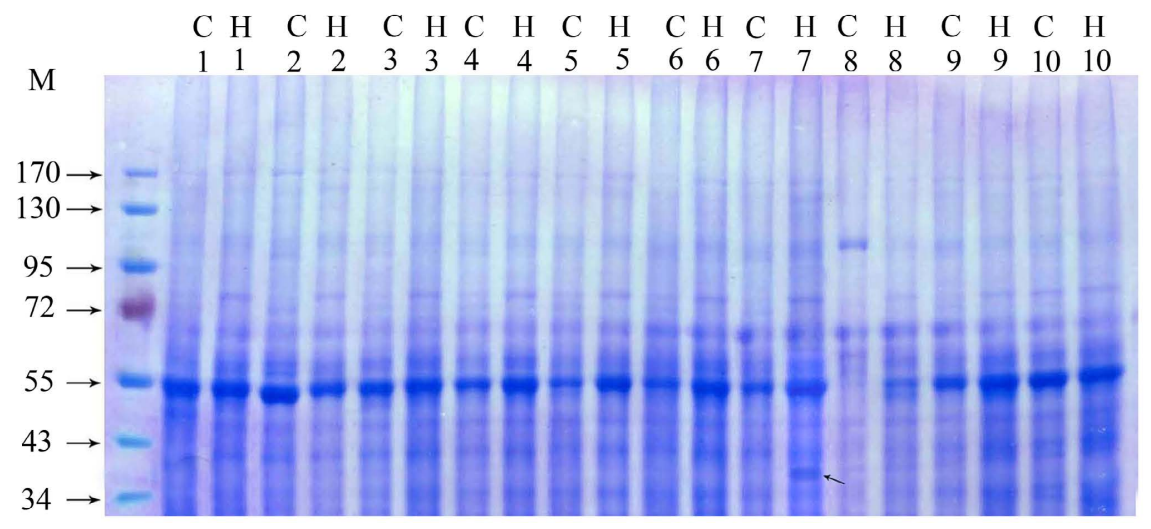

(a)

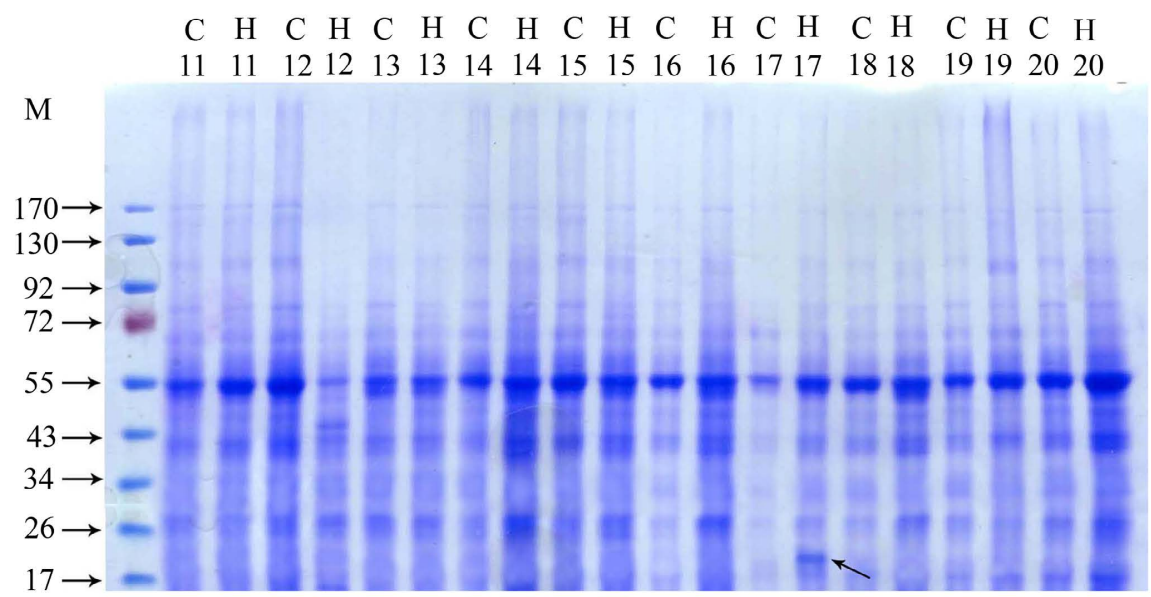

(b)

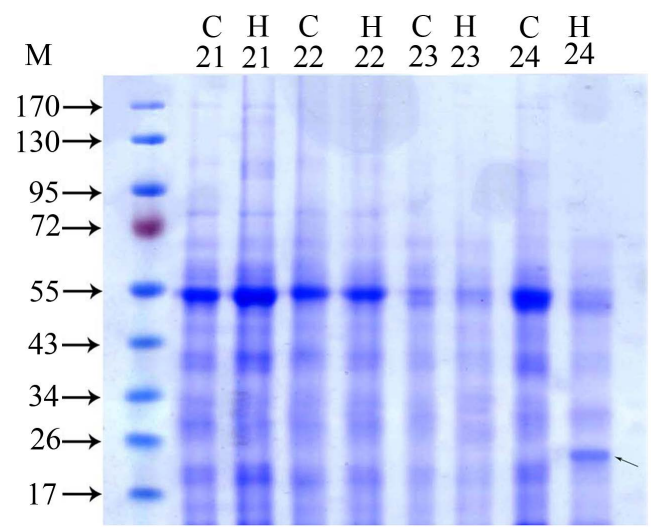

(c)

Figure 1. (a) Gel showing protein bands in ten wheat genotypes (G.1 - G.10) under control and heat stress conditions. $\mathrm{H}=$ heat stressed; $\mathrm{C}=$ Control; (b) Gel showing protein bands in ten wheat genotypes (G.11 - G.20) under control and heat stress conditions; (c) Gel showing protein bands in four wheat genotypes (G.21 - G.24) under control and heat stress conditions.

Heat stress markedly decreased plant biomass; maximum decrease was observed in G.18 (48\%) while, minimum was observed in G.7, G.17, G.12 and G.24. Heat stress significantly affected 100 grain weight in wheat genotypes. Maximum 
reduction (36\%) in 100 grain weight was observed in G.15. Whereas, G.7, G.12, G.17 and G.19 were observed with minimum reduction. Significantly higher reduction in number of spikelets/spike was recorded for G.22 (23\%). Least reduction in the number of spikelets/spike was found in G.7 followed by G.17, G.19 and G.12 respectively. Maximum reduction (34\%) number of florets per spike was shown by G.21 whereas; minimum decrease was shown by G.1 followed by G.7, G.17 and G.19 as compared to control (Table 2).

Heat stress is a common restriction during anthesis and grain filling stages in many cereal crops of temperate regions. At the reproductive phases, fertilization is one of the most sensitive stages to high temperature in various plants. During wheat grain filling it reduces kernel growth leading to loss in kernel density and weight [37] [38] [39] [40]. Behavior of different genotypes was different for heat stress imposed at the pre-anthesis stage. The maximum decrease in plant biomass and 100 grain weight was observed in G.18. However, some genotypes showed the minimum effects of heat stress. For example, G.7, G.12 and G.17 showed the minimum effect of heat stress on number of spikelets per spike, plant biomass and 100 grain weight, respectively. This behavior of genotypes indicates that these genotypes have the ability to tolerate heat stress. Ferris et al. [41] also found that imposition of heat stress in wheat at anthesis stage caused decrease in grain yield and biomass. Grain yield was negatively related to the thermal time accumulated above the base temperature of $31^{\circ} \mathrm{C}$ [42].

\section{Conclusion}

Wheat is more sensitive to heat stress at the pre-anthesis growth stage. Under high temperature stress, activities of SOD and POD, protein and proline contents of different wheat genotypes increased, and new heat shock proteins were isolated from these genotypes which triggered the high temperature tolerance mechanism in these genotypes. Nevertheless, on the basis of yield, physiological and molecular attributes wheat genotypes G.7 and G.17 were declared tolerant to high temperature. The high temperature stress triggered antioxidant defensive mechanism in these two cultivars which helped to survive under heat stress environment. The information generated through present investigation will be helpful for plant breeders to include these traits in the breeding program for the development of heat tolerant wheat cultivars.

\section{Conflicts of Interest}

The authors declare no conflicts of interest regarding the publication of this paper.

\section{References}

[1] Foolad, M.R. (2005) Breeding for Abiotic Stress Tolerances in Tomato. In: Ashraf, M. and Harris, P.J.C., Eds., Abiotic Stresses: Plant Resistance through Breeding and Molecular Approaches, The Haworth Press Inc., New York, 613-684. 
[2] Verslues, P.E. and Sharma, S. (2010) Plant-Environment Interaction: Proline Metabolism and Its Implications for Plant-Environment Interaction. The Arabidopsis Book, No. 8, e0140. https://doi.org/10.1199/tab.0140

[3] Vetter, J.L., Steinberg, M.P. and Nelson, A.I. (1958) Quantitative Determination of Peroxidase in Sweet Corn. Journal of Agricultural and Food Chemistry, 6, 39-41. https://doi.org/10.1021/jf60083a006

[4] Ahmed, J.U. and Hasan, M.A. (2011) Evaluation of Seedling Proline Content of Wheat Genotypes in Relation to Heat Tolerance. Bangladesh Journal of Botany, 40, 17-22. https://doi.org/10.3329/bjb.v40i1.7991

[5] Ullah A, Bano A and Khan N (2021) Climate Change and Salinity Effects on Crops and Chemical Communication between Plants and Plant Growth-Promoting Microorganisms under Stress. Frontiers in Sustainable Food Systems, 5, Article ID: 618092. https://doi.org/10.3389/fsufs.2021.618092

[6] Chutipaijit, S., Cha-um, S. and Sompornpailin, K. (2009) Differential Accumulations of Proline and Flavonoids in Indica Rice Varieties against Salinity. Pakistan Journal of Botany, 41, 2497-2506.

[7] Almeselmani, M., Deshmukh, P.S., Sairam, R.K., Kushwaha, S.R. and Singh, T.P. (2006) Protective Role of Antioxidant Enzymes under High Temperature Stress. Plant Science, 171, 382-388. https://doi.org/10.1016/j.plantsci.2006.04.009

[8] Apse, M.P. and Blumwald, E. (2002) Engineering Salt Tolerance in Plants. Current Opinion in Biotechnology, 13, 146-150. https://doi.org/10.1016/S0958-1669(02)00298-7

[9] Khan, N., Ali, S., Shahid, M.A. and Kharabian-Masouleh, A. (2017) Advances in Detection of Stress Tolerance in Plants through Metabolomics Approaches. Plant Omics, 10, 153-163. https://doi.org/10.21475/poj.10.03.17.pne600

[10] Din, R., Subhani, G., Ahmad, N., Hussain, M. and Rhman, A. (2010) Effect of Temperature on Development and Grain Formation in Spring Wheat. Pakistan Journal of Botany, 42, 899-906.

[11] Abdelrahman, M., Selim, M.E., ElSayed, M.A., Ammar, M.H., Hussein, F.A., ElKholy, N.K., ElShamey, E.A., Khan, N. and Attia, K.A. (2021) Developing Novel Rice Genotypes Harboring Specific QTL Alleles Associated with High Grain Yield under Water Shortage Stress. Plants, 10, 2219.

[12] Esfandiari, E., Shekari, F., Shekari, F. and Esfandiari, M. (2007) The Effect of Salt Stress on Antioxidant Enzymes Activity and Lipid Peroxidation on the Wheat Seedling. Notulae Botanicae Horti Agrobotanici Cluj-Napoca, 35, 48-56.

[13] Riaz, M.W., Yang, L., Yousaf, M.I., Sami, A., Mei, X.D., Shah, L., Rehman, S., Xue, L., Si, H. and Ma, C. (2021) Effects of Heat Stress on Growth, Physiology of Plants, Yield and Grain Quality of Different Spring Wheat (Triticum aestivum L.) Genotypes. Sustainability, 13, Article No. 2972. https://doi.org/10.3390/su13052972

[14] Hall, A.E. (2001) Crop Responses to Environment. CRC Press LLC, Boca Raton.

[15] Bates, L.S., Waldern, R. and Teare, I.D. (1973) Rapid Determination of Free Proline for Water Stressed Studies. Plant Soil, 39, 205-207.

https://doi.org/10.1007/BF00018060

[16] Hamada, A.M. and El-Enany, A.E. (1994) Effect of $\mathrm{NaCl}$ Salinity on Growth, Pigment and Mineral Element Contents, and Gas Exchange of Broad Bean and Pea Plants. Biologia Plantarum, 36, 75-81. https://doi.org/10.1007/BF02921273

[17] Chinnusamy, V. and Khanna-Chopra, R. (2003) Effect of Heat on Grain Starch Content in Diploid, Tetrapolid and Hexaploid Wheat Species. Journal of Agronomy 
and Crop Science, 189, 242-249. https://doi.org/10.1046/j.1439-037X.2003.00036.x

[18] Khan, N. and Ali, S. (2017) Advances in the Detection of Genetic Diversity in Bread Wheat. American Journal of Agricultural Science, 4, 29-36.

[19] Beauchamp, C. and Fridovich, I. (1971) Superoxide Dismutase: Improvement Assay Applicable to Acryl Amide Gels. Analytical Biochemistry, 44, 276-278. https://doi.org/10.1016/0003-2697(71)90370-8

[20] Steel, R.G.D. and Torrie, J.H. (1984) Principal and Procedures of Statistics. McGraw Hill, New York.

[21] Stone, P. and Nicholas, M.E. (1994) Wheat Cultivars Vary Widely in Their Responses of Grain Yield and Quality to Short Periods of Post-Anthesis Heat Stress. Australian Journal of Plant Physiology, 21, 887-900. https://doi.org/10.1071/PP9940887

[22] Wahid, A. and Close, T.J. (2007) Expression of Dehydrins under Heat Stress and Their Relationship with Water Relations of Sugarcane Leaves. Biologia Plantarum, 51, 104-109. https://doi.org/10.1007/s10535-007-0021-0

[23] Khan, M.N.N., Ahmad, Z. and Ghafoor, A. (2011) Genetic Diversity and Disease Response of Rust in Bread Wheat Collected from Waziristan Agency, Pakistan. International Journal of Biodiversity and Conservation, 3, 10-18.

[24] Hasan, M.A., Ahmed, J.U., Bahadur, M.M., Haque, M.M. and Sikder, S. (2007) Effect of Late Planting Heat Stress on Membrane Thermostability, Proline Content and Heat Susceptibility Index of Different Wheat Cultivars. Journal of the National Science Foundation of Sri Lanka, 35, 109-117. https://doi.org/10.4038/jnsfsr.v35i2.3675

[25] Khan, N., Zandi, P., Ali, S., Mehmood, A., Adnan Shahid, M. and Yang, J. (2018) Impact of Salicylic Acid and PGPR on the Drought Tolerance and Phytoremediation Potential of Helianthus annus. Frontiers in Microbiology, 9, Article No. 2507. https://doi.org/10.3389/fmicb.2018.02507

[26] Parent, B., Turc, O., Gibon, Y., Stitt, M. and Tardieu, F. (2010) Modeling Temperature-Compensated Physiological Rates, Based on the Coordination of Responses to Temperature of Developmental Processes. Journal of Experimental Botany, 61, 2057-2069. https://doi.org/10.1093/jxb/erq003

[27] Wheeler, T.R., Hong, T.D., Ellis, R.H., Batts, G.R., Morison, J.I.L. and Hardley, P. (1996) The Duration and the Rate of Grain Growth, and Harvest Index, of Wheat (Tritium aestivum) in Response to Temperature and $\mathrm{CO}_{2}$. Journal of Experimental Botany, 47, 623-630. https://doi.org/10.1093/jxb/47.5.623

[28] You, L., Rosegrant, M.W., Wood, S. and Sun, D. (2009) Impact of Growing Season Temperature on Wheat Productivity in China. Agricultural and Forest Meteorology, 149, 1009-1014. https://doi.org/10.1016/j.agrformet.2008.12.004

[29] Porter, J.R. (2005) Rising Temperatures Are Likely to Reduce Crop Yields. Nature, 436, 174. https://doi.org/10.1038/436174b

[30] Prasad, M., Varshney, R.K., Roy, J.K., Balyan, H.S. and Gupta, P.K. (2000) The Use of Microsatellites for Detecting DNA Polymorphism, Genotype Identification and Genetic Diversity in Wheat. Theoretical and Applied Genetics, 100, 585-592. https://doi.org/10.1007/s001220050077

[31] Ronde, J., Mescht, A. and Steyn, H.S.F. (2001) Proline Accumulation in Response to Drought and Heat Stress in Cotton. African Crop Science Journal, 8, 85-92. https://doi.org/10.4314/acsj.v8i1.27718

[32] Sairam, R.K., Srivastava, G.C. and Saxena, D.C. (2000) Increased Anti-Oxidant Ac- 
tivity under Elevated Temperatures: A Mechanism of Heat Stress Tolerance in Wheat Genotypes. Biologia Plantarum, 43, 245-251. https://doi.org/10.1023/A:1002756311146

[33] Sato, S., Kamiyama, M., Iwata, T., Makita, N., Furukawa, H. and Ikeda, H. (2006) Moderate Increase of Mean Daily Temperature Adversely Affects Fruit Set of Lycopersicon esculentum by Disrupting Specific Physiological Processes in Male Reproductive Development. Annals of Botany, 97, 731-738.

https://doi.org/10.1093/aob/mcl037

[34] Jaleel, C.A., Gopi, R., Manivannan, P. and Panneerselvam, R. (2007) Antioxidative Potentials as a Protective Mechanism in Catharanthus roseus (L.) Plants under Salinity Stress. Turkish Journal of Botany, 31, 245-251.

[35] Billah, M., Khan, M., Bano, A., Nisa, S., Hussain, A., Dawar, K.M., Munir, A. and Khan, N. (2020) Rock Phosphate-Enriched Compost in Combination with Rhizobacteria: A Cost-Effective Source for Better Soil Health and Wheat (Triticum aestivum) Productivity. Agronomy, 10, Article No. 1390.

https://doi.org/10.3390/agronomy10091390

[36] Jones, P.D., New, M., Parker, D.E., Mortin, S. and Rigor, I.G. (1999) Surface Area Temperature and Its Change over the Past 150 Years. Reviews of Geophysics, 37, 173-199. https://doi.org/10.1029/1999RG900002

[37] Laemmli, D.K. (1970) Cleavage of Structural Proteins in Assembly of the Heat of Bacteriophage T4. Nature, 227, 680-685. https://doi.org/10.1038/227680a0

[38] Khan, N. and Bano, A. (2019) Exopolysaccharide Producing Rhizobacteria and Their Impact on Growth and Drought Tolerance of Wheat Grown under Rainfed Conditions. PLoS ONE, 14, Article ID: e0222302.

https://doi.org/10.1371/journal.pone.0222302

[39] Lv, W.-T., Lin, B., Zhang, M. and Hua, X.J. (2011) Proline Accumulation Is Inhibitory to Arabidopsis Seedlings during Heat Stress. Plant Physiology, 156, 1921-1933. https://doi.org/10.1104/pp.111.175810

[40] Qaseem, M.F., Qureshi, R. and Shaheen, H. (2019) Effects of Pre-Anthesis Drought, Heat and Their Combination on the Growth, Yield and Physiology of Diverse Wheat (Triticum aestivum L.) Genotypes Varying in Sensitivity to Heat and Drought Stress. Scientific Reports, 9, Article No. 6955. https://doi.org/10.1038/s41598-019-43477-z

[41] Ferris, R., Ellis, R.H., Wheeler, T.R. and Hadley, P. (1998) Effect of High Temperature Stress at Anthesis on Grain Yield and Biomass of Field-Grown Crops of Wheat. Annals of Botany, 82, 631-639. https://doi.org/10.1006/anbo.1998.0740

[42] Chowdhury, M.K., Hasan, M.A., Bahadur, M.M., Islam, M., Hakim, M., Iqbal, M.A., Javed, T., Raza, A., Shabbir, R., Sorour, S. and Elsanafawy, N.E. (2021) Evaluation of Drought Tolerance of Some Wheat (Triticum aestivum L.) Genotypes through Phenology, Growth, and Physiological Indices. Agronomy, 11, Article No. 1792.

https://doi.org/10.3390/agronomy11091792 